\title{
Sistem Pemantauan Pengobatan Pasien TB Paru di Puskesmas Kabupaten Kudus
}

\author{
Ari Setiawan*, Sutopo Patria Jati**, Farid Agushybana** \\ * Dinas Kesehatan Kabupaten Tebo, Jambi \\ **Staf Pengajar Program Magister Ilmu Kesehatan Masyarakat Universitas Diponegoro \\ Email :ari_paster@yahoo.co.id
}

\section{ABSTRACT}

Treatment records of patients with pulmonary tuberculosis (TB) in Kudus District Puskemas have not gone well, especially in terms of treatment schedules. Where on the medication recording sheet there is a sheet that is kept by the officer and there is a sheet that is taken by the patient. In sending messages to patients, officers still have to find patient contact through patient records stored in the data box manually. This has caused officers to experience problems in monitoring patients for treatment schedules. The purpose of this study is to develop the related Information Systems that can be used to monitor patient treatment, send reminder messages and produce report recaps to support the evaluation of the Pulmonary TB Program in Kudus Regency.

The type of research used is research actions in the form of system development. System development uses the FAST method (Framework for the Application of System Techniques). The research subjects consisted of 5 respondents consisting of the head of the infectious disease management section, the manager of pulmonary TB in the Health Office and 3 officers of the Pulmonary Pulmonary TB Unit.

The result of this development is a webbased information system with the SMS gateway feature. With this system, officers are easier to monitor patient treatment. In the patient list you can see the treatment schedule based on the date desired by the officer. In sending reminder messages it is easier to do because the patient's mobile number is stored in the database system. In addition to that, the medical treatment report for patients with pulmonary TB was recapitulated, and the patient's treatment chart was also in accordance with those in the Puskesmas.

Keywords: Information System, Pulmonary TB, Public Health Service

\section{PENDAHULUAN}

Tuberculosis atau TB Paru masih menjadi salah satu masalah kesehatan masyarakat, meskipun strategi pengobatan dengan metode DOTS sudah dilaksanakan sejak tahun 1995, jumlah kasus TB Paru meningkat dan banyak yang tidak berhasil disembuhkan, terutama pada negara yang dikelompokkan dalam 22 negara dengan masalah TB besar (high burden countries). Menyikapi hal tersebut, pada tahun 1993, WHO mencanangkan TB Paru sebagai kedaruratan dunia (global emergency) ${ }^{1}$.

Indonesia berada pada ranking kelima negara dengan beban TB tertinggi di dunia. Untuk mencapai tujuan penanggulangan TB paru ditetapkan program jangka panjang, yaitu menurunkan angka kesakitan dan angka kematian penyakit TB dengan cara memutuskan rantai penularan.

Puskesmas di wilayah Kecamatan Kota pada Kabupaten Kudus pada Tahun 2014 (3 Puskesmas), jumlah kasus TB dengan BTA positif sebanyak 41 kasus, meningkat menjadi 54 kasus pada tahun 2016. Untuk pasien yang mengalami konversi dari tahun $2015(32,6 \%)$ masih jauh dari target yang 
ditentukan (80\%), demikian juga untuk tahun 2016 baru mencapai $50 \% .^{23}$

Perkembangan teknologi yang semakin pesat dewasa ini memungkinkan semua orang dapat berperan dalam membantu program penanggulangan penyakit TB Paru. Salah satunya adalah tekhnologi Short Message Service (SMS). Teknologi ini telah lama dikenal dan di gunakan oleh masyarakat, sebelum muncul teknologi-teknologi pengiriman pesan yang sekarang beragam jenisnya. Data dari Kementerian Komunikasi dan Informasi menyebutkan bahwa di Indonesia ada sekitar 338.948.340 penduduk yang menggunakan handphone sebagai alat komunikasi pada tahun $2015 .^{4}$

Berdasarkan studi pendahuluan dan anlisa terhadap pencatatan pengobatan pasien TB paru terdapat beberapa kelemahan. Antara lain, jadwal minum pasien yang dicatat pada lembar TB 01 disimpan di Puskesmas, sedangkan jadwal pengambilan obat kembali dan jadwal pemeriksaan dahak ulang disimpan oleh pasien. Dari kondisi ini petugas mengalami kendala dalam memantau berapa jumlah pasien yang harus kembali dan jadwal pemeriksaan dahak pasien.

Dari penjabaran diatas, perlu adanya suatu sistem informasi yang dapat menghasilkan informasi tentang jadwal pengambilan obat, jadwal minum obat, jadwal pemeriksaan dahak ulang untuk keberhasilan pengobatan TB Paru di Puskesmas Kabupaten Kudus.

Tuberkulosis adalah suatu infeksi menular dan menahun dan bisa berakibat fatal, yang disebabkan oleh Mycobacterium tuberculosis, Mycobacterium bovis atau Mycobacterium africanum. Mycobacterium tuberculosis termasuk basil gram positif, berbentuk batang, dinding selnya mengandung komplek lipidaglikolipida serta lilin (wax) yang sulit ditembus zat kimia. Umumnya Mycobacterium tuberculosis menyerang paru dan sebagian kecil organ tubuh lain. Kuman ini mempunyai sifat khusus, yakni tahan terhadap asam pada pewarnaan. ${ }^{5}$

Pemantauan kemajuan dan hasil pengobatan dilaksanakan dengan pemeriksaan ulang dahak secara mikroskopis. Untuk memantau kemajuan pengobatan dilakukan pemeriksaan dua contoh uji dahak. Hasil pemeriksaan dinyatakan negatif bila ke 2 contoh uji dahak tersebut negatif. Bila salah satu contoh uji positif, hasil pemeriksaan ulang dahak tersebut dinyatakan positif. Pemeriksaan ulang dahak pasien TB BTA positif merupakan suatu cara terpenting untuk menilai hasil kemajuan pengobatan.. Pada semua pasien TB Paru BTA positif, pemeriksaan ulang dahak selanjutnya dilakukan pada bulan ke $5 .^{6}$

Sistem adalah sekumpulan dari komponen-komponen yang saling berhubungan satu dengan yang lain membentuk satu kesatuan untuk mencapai tujuan tertentu. Komponen-komponen sistem atau elemen-elemen sistem dapat berupa suatu subsistem atau bagian-bagian dari sistem. Komponen tersebut terdiri dari lima sumber daya yang dikenal sebagai komponen sistem informasi. Kelima sumber daya tersebut adalah manusia, hardware, software, data, dan jaringan. Kelima komponen tersebut memainkan peranan yang sangat penting dalam suatu sistem informasi, tapi dalam kenyataannya tidak semua sistem informasi mencakup kelima komponen tersebut.

Pada proses pengembangan sistem terdapat beberapa tahapan. Tahapan pada metode FAST meliputi, studi pendahuluan, analisis masalah, analisis kebutuhan, analisis keputusan, tahap perancangan sistem, tahap pembangunan sistem, tahap penerapan/ujicoba sistem dan evaluasi sistem. ${ }^{78}$

SMS Gateway adalah sistem yang digunakan untuk mempermudah seseorang atau sebuah perusahaan mengirimkan pesan SMS yang sama dalam waktu yang bersamaan pada banyak orang. SMS Gateway dapat terhubung ke media lain seperti perangkat SMSC dan server milik Content Provider melalui link IP untuk memproses suatu layanan SMS. Sebuah sistem SMS Gateway, umumnya terdiri komponen hardware (server/komputer yang dilengkapi dengan perangkat jaringan) dan software (Aplikasi yang digunakan untuk pengolahan pesan). Untuk sebuah sistem yang besar umumnya dapat menggunakan database untuk penyimpanan data. 9,10

\section{METODE PENELITIAN}

Penelitian ini menggunakan dua metode penelitian yaitu kualitatif dan kuantitatif. Metode kualitatif pada penelitian ini digunakan untuk membantu proses identifikasi pada setiap tahapan pengembangan sistem, dimana hasil akhirnya terbentuk suatu rancangan sistem informasi 
pemantauan pengobatan pasien di Puskesmas Kabupaten Kudus. Metode kuantitatif digunakan untuk melakukan evaluasi kualitas ketergunaan sistem informasi setelah dikembangkan.

Subyek pada penelitian ini terdiri dari 1 orang Kepala Seksi Penanggulangan Penyakit Menular, 1 orang Wakil Supervisor TB Paru di Dinas Kesehatan, 3 orang pemegang program TB Paru di Puskesmas, sedangkan untuk evaluasi ketergunaan sistem informasi sebanyak 12 petugas TB Paru di Puskesmas.

Pada proses pengembangan sistem menggunakan metodologi tahapan FAST (Framework for application of system tehnique). Tahapan FAST meliputi studi pendahuluan, analisis masalah, analisis kebutuhan, analisis keputusan, tahap perancangan sistem, tahap pembangunan sistem, tahap penerapan/ujicoba sistem dan evaluasi sistem.

Pengumpulan data dilakukan dengan observasi dan wawancara mendalam serta menggunakan kuesioner. Analisis isi digunakan untuk menganalisis data kualitatif yang berasal dari hasil wawancara mendalam dan pengamatan. Analisis deskriptif digunkan untuk mengukur tingkat persetujuan pengguna terhadap item-item pertanyaan kuesioner dengan bentuk score tujuh poin skala likert, sehingga diperoleh data yang memudahkan untuk penghitungan. Penelitian ini dibatasi sampai pada tahap ujicoba sistem.

\section{HASIL DAN PEMBAHASAN}

Pengembangan yang akan dilakukan pada sistem Informasi pemantauan pengobatan pasien TB paru yaitu dengan memperbaiki sistem yang ada. Faktor-faktor yang mendorong pengembangan sistem yang lama adalah adanya masalah, peluang dan arahan dari pemegang program di Puskemas dan di Dinas Kesehatan. Tahapan yang digunakan dalam pengembangan pada sistem ini dengan menggunakan metode FAST (Framework for the Application of System Technique).

\section{Identifikasi Model Sistem}

Mengidentifikasi masalah merupakan langkah awal yang dilakukan pada tahapan analisis masalah. Hasil identifikasi masalah inilah yang dijadikan dasar dalam melakukan pengembangan sistem tersebut dari input, proses dan output dari sistem saat ini. Dari hasil wawancara mendalam masalah yang ada dalam pemantauan pengobatan pasien TB paru adalah 1) kendala tentang informasi jadwal pengobatan, jadwal pengambilan obat dan jadwal pemeriksaan dahak, 2) pencatatan dalam lembaran kertas, sehingga untuk menyajikan output belum sesuai kebutuhan pimpinan, 3) keterlambatan informasi penyampaian pesan kepada pasien.

Peluang dapat dilihat dari keinginan para petugas yang terkait dengan sistem informasi program TB untuk meningkatkan mutu kegiatan pelayanan kesehatan penderita TB dengan mengoptimalkan fungsi teknologi saat ini dengan adanya komputer, internet dan telepon, karena selama ini untuk melihat dan mengingatkan pasien harus melihat secara manual dari berkas-berkas catatan manual.

Dari hasil observasi dan wawancara diperoleh hasil ruang lingkup cakupan pengembangan sistem informasi pemantauan pengobatan pasien TB Paru adalah jadwal minum obat, jadwal pengambilan obat dan jadwal pemeriksaan dahak ulang yang dapat menghasilkan output berupa pesan kepada pasien TB Paru tentang jadwal pengobatannya, rekapan pelaporan program TB Paru berupa tabel, grafik penderita TB Paru per desa, dan pemetaan penyebaran pasien di puskesmas.

Kelayakan untuk pengembangan sistem informasi ini di dukung oleh kelayakan teknis, berupa fasilitas CPU, laptop, server, printer dan petugas di Puskesmas. Sedangkan untuk kelayakan operasi di dukung oleh kemampuan petugas yang bisa mengoperasikan komputer, kemampuan sistem menghasilkan informasi dan efisiensi waktu petugas dalam megingatkan pasien.

Selain kelayakan teknis dan operasional, dilihat dari sistem informai juga melihat kelayakan ekonomi. Hal ini untuk digunakan untuk mengukur apakah sistem informasi ini dapat dibiayai dan memberikan manfaat dalam membangun sistem ini. Dari hasil wawancara diperoleh bahwa dinas kesehatan kudus mempunyai anggaran dan pemeliharaan, sedangkan evaluasi sistem dilakukan pada saat evaluasi program triwulanan.

2. Pengembangan Sistem Informasi

Pemantauan Pengobatan Pasien TB Paru

Model pengembangan sistem informasi yang dikembangkan dilakukan melalui 
pendekatan top down. Pendekatan ini dengan melibatkan pengguna dari petugas TB Paru di Dinas Kesehatan Kabupaten Kudus dan petugas TB Paru di Puskesmas dalam proses desainnya, sehingga model sistem informasi yang dikembangkan mudah dipahami dan diterima pengguna. ${ }^{7}$

Sistem informasi ini meliputi hal-hal sebagai berikut:

1. Sistem informasi ini dapat memantau jadwal pengobatan pasien dalam minum obat, pengambilan obat kembali dan pemeriksaan dahak ulang.

2. Output dari system informasi ini berupa pesan pengingat, tabel, dan grafik.

Sistem operasi merupakan program yang bertindak sebagai perantara antara pemakai komputer dan perangkat keras komputer. Tujuan sistem operasi adalah menyediakan lingkungan yang memungkinkan pemakai dapat menjalankan program apapun dengan mudah ${ }^{11}$. Pada penelitian ini penentuan sistem operasi pada sistem informasi pemantauan pengobatan pasien TB Paru di Puskesmas Kabupaten Kudus menggunakan sistem operasi Microsoft (MS) Windows. Sistem ini dipilih karena dari hasil pengamatan pengoperasian perangkat komputer di Puskesmas maupun di Dinas Kesehatan Kabupaten Kudus menggunakan sistem ini untuk pekerjaan sehari-hari, sehingga petugas sudah terbiasa dengan sistem operasi ini.

Sedangkan software (tools) yang dapat digunakan untuk membangun sistem informasi program TB antara lain Microsoft Visual Basic (MS VB), Hypertext Preprocessor (PHP), dan Borland Delphi. Kelebihan bahasa pemrograman adalah $\mathrm{PHP}^{12}$ :

a. PHP dikategorikan sebagai bahasa pemrograman yang mudah dimengerti oleh manusia dan berbasis visual.

b. PHP merupakan bahasa pemrograman yang open source (gratis)

Untuk basis data menggunakan MySQL, karena sesuai dengan system operasi $M S$ Windows dan open source.

Berdasarkan hasil identifikasi maka model sistem informasi pemantauan pengobatan pasien TB Paru dapat dikembangkan sebagai berikut:

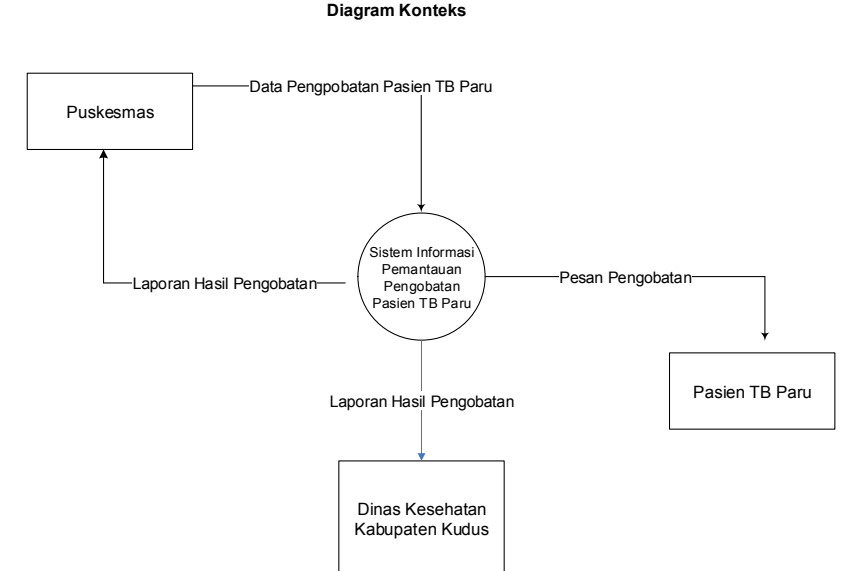

Gambar 1. Diagram Konteks Sistem Informasi Pemantauan Pengobatan Pasien TB Paru

Entitas yang terdapat pada sistem informasi imunisasi di atas dapat dijelaskan sebagai berikut:

1) Dinas Kesehatan Kabupaten Kudus

Entitas ini harus melakukan Log In terlebih dahulu, kemudian system akan menyediakan informasi berupa rekapan hasil pengobatan sesuai yang di inginkan.

a. Rekapan pengobatan pasien TB Paru berdasarkan puskesmas.

b. Grafik Pasien TB Paru secara keseluruhan kabupaten dan per desa. c. Pemetaan penyebaran pasien
berdasarkan puskesmas.

2) Puskemas

Entitas ini melakukan Log In terlebih dahulu, kemudian menginput data pasien yang berobat, menginput jadwal tanggal pengambilan obat, tanggal pengambilan obat kembali, dan jadwal pemeriksaan dahak. Selanjutnya sistem akan menyediakan data list pasien yang sedang dalam pengobatan, jadwal pengiriman pesan pengingat, rekap pasien TB Paru yang berobat, dan grafik pengobatan per desa.

\section{3) Pasien TB Paru}

Entitas ini menerima pesan berdasarkan jadwal pengobatan yang disediakan oleh sistem informasi.

Setelah diagram konteks digambarkan maka diagram konteksakan diturunkan dalam bentuk yang lebih rinci yang disebut Diagram Alir Data (DAD) yang bertujuan untuk mendefinisikan proses apasaja yang terdapat dalam sistem yang akan dibangun. 


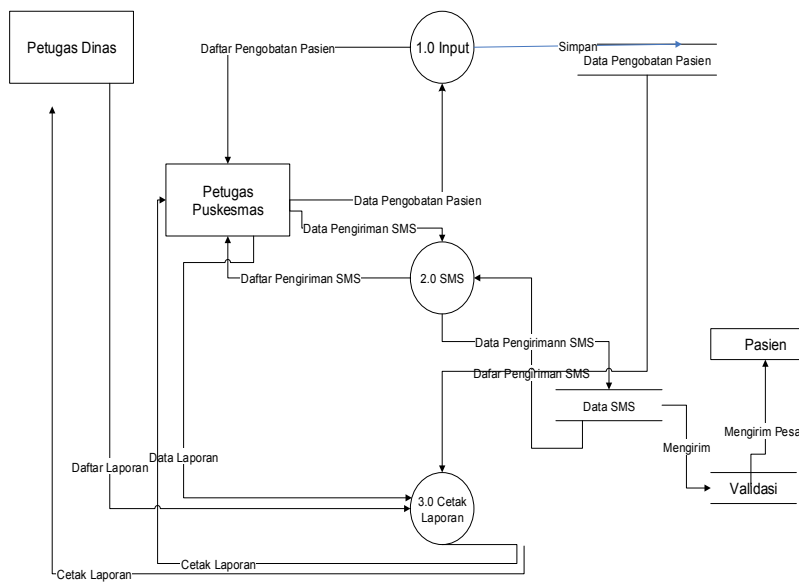

Gambar 2. Diagram Alir Data Level 0 Sistem Informasi Pemantauan Pengobatan Pasien TB Paru

Sistem informasi pemantauan pengobatan pasien TB Paru dapat dibagi atas tiga komponen penting yaitu :

a) Input

Pada proses input ini, yang memasukkan data ke dalam sistem informasi dilakukan oleh petugas pengelola data TB Paru di Puskesmas. Data yang dimasukkan meliputi data NIK, nama pasien, alamat pasien, no hp, tanggal mulai minum obat, tanggal pengambilan obat kembali, tanggal pemerikaan dahak ulang, dan hasil pengobatan.

b) Proses

Proses atau transaksi adalah kegiatan mengolah data input berupa menjumlah, merekap, dan lain - lain yang menghasilkan output berupa laporan pengobatan pasien TB paru, pengiriman pesan pengingat kepada pasien TB tentang jadwal pengobatan.

\section{c) Output}

Output adalah hasil dari proses yang pada sistem ini menyediakan output dalam bentuk pesan pengingat pengobatan, tabel, grafik maupun pemetaan untuk informasi penyebaran pasien TB Paru. sedangkan output dalam bentuk tabel saja untuk laporan pengobatan pasien dan data list pasien.

a. Tahap pengembangan Sistem

Tujuan dari tahap ini adalah membangun (pemrograman) dan menguji sistem sesuai kebutuhan dan spesifikasi rancangan, mengimplementasikan interface sistem baru. Sistem yang dikembangkan terdiri dari proses yang terdiri dari input data pasien, jadwal pengobatan, jadwal pengambilan obat dan jadwal pemeriksaan dahak ulang. Setelah diproses oleh sistem informasi, output yang dihasilkan adalah pesan kepada pasien TB Paru tentang jadwal pengobatannya, rekap list pasien Puskesmas, rekap pasien semua Puskesmas, dan grafik.

Berikut ini adalah tampilan hasil pengembangan sistem informasi pemantauan pengobatan Pasien TB Paru:

a. Menu login

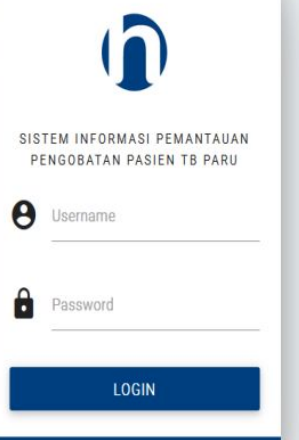

Gambar 3 Menu Login Sistem Informasi Pemantauan Pengobatan Pasien TB Paru

Halaman login digunakan untuk membatasi hak akses penggunanya dalam hal melakukan pengoperasian sistem untuk mendukung keamanan data dan informasi dari pengaksesan yang tidak diinginkan. Pada sistem ini terdapat dua level pengguna, yaitu Puskesmas dan Dinas Kesehatan.

b. Menu beranda

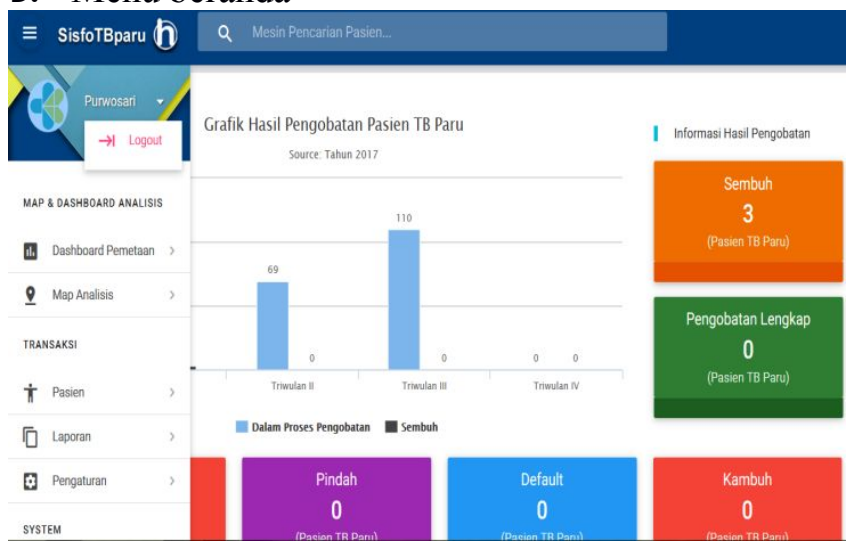

Gambar 4 Menu Utama Sistem Informasi Pemantauan Pengobatan Pasien TB Paru

Setelah login dengan memasukkan username dan password untuk level puskesmas maka akan muncul tampilan menu utama sebagai Puskesmas yang menyajikan menu data input, laporan, grafik, pemetaan, setting data pengguna, SMS Gateway dan log out. 
c. Menu input pasien

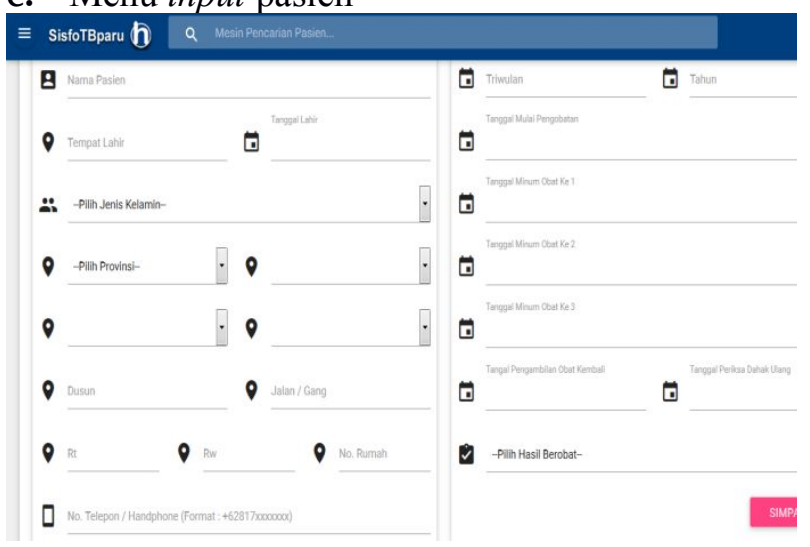

Gambar 5 Gambar Menu Input Pasien Sistem Informasi Pemantauan Pengobatan Pasien TB Paru

Pada tampilan menu input pasien adalah NIK, nama, tempat tangal lahir, alamat, nomor handphone, triwulan pengobatan, jadwal pengobatan, jadwal minum obat, jadwal pengambilan obat dan jadwal pemeriksaan dahak.

d. Menu List Pasien

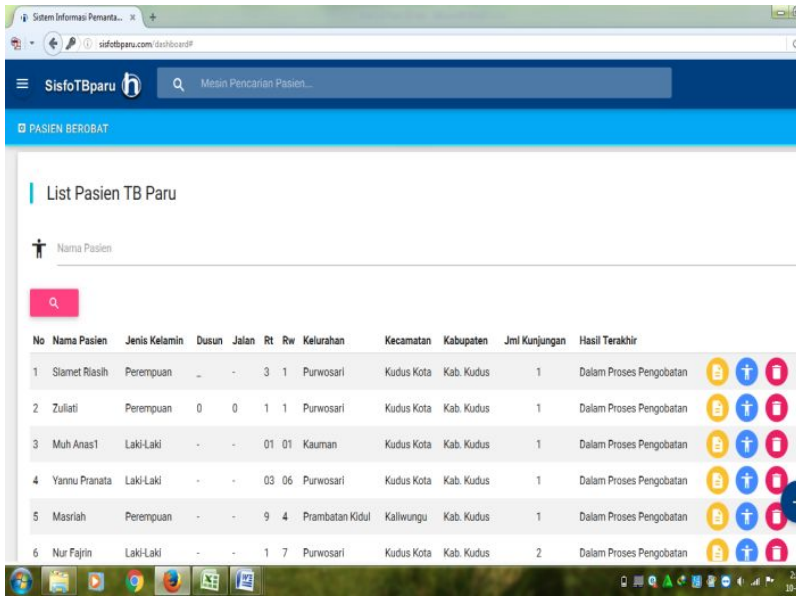

Gambar 6 Menu List Pasien Sistem Informasi Pemantauan Pengobatan Pasien TB Paru

Pada menu untuk melihat list pasien yang sedang dalam masa pengobatan di Puskesmas. Disamping itu petugas dapat mengedit data pasien apabila diperlukan untuk mengubah tanggal jadwal minum obat, jadwal pengambilan obat dan jadwal pemeriksaan dahak selanjutnya. Dengan menginput edit jadwal, petugas dapat melihat rincian setiap pasien jadwal pengobatan masing-masing individu, sehingga petugas terbantu dalam memantau masing-masing pasien.

\section{e. Menu SMS Gateway}

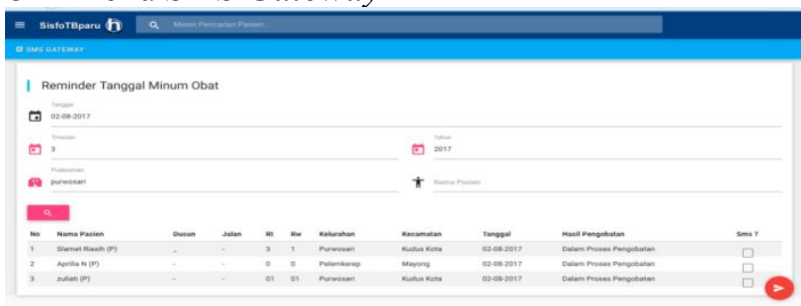

Gambar 7 Tampilan menu Pengingat Minum Obat Sistem Informasi Pemantauan Pengobatan Pasien TB Paru

Pada menu pengingat minum obat pasien, petugas dapat menginputkan tanggal yang dikehendaki untuk melihat pasien mana saja yang harus minum obat pada tanggal yang dikehendaki. Selain itu petugas juga dapat melihat tanggal dan nama pasien yang dikehendaki di menu pencarian, sehingga dengan menu ini petugas dapat langsung mengirimkan pesan pengobatan tanpa harus memasukkan nomor handphone, karena sudah tersimpan di database.

\section{f. Menu Grafik}

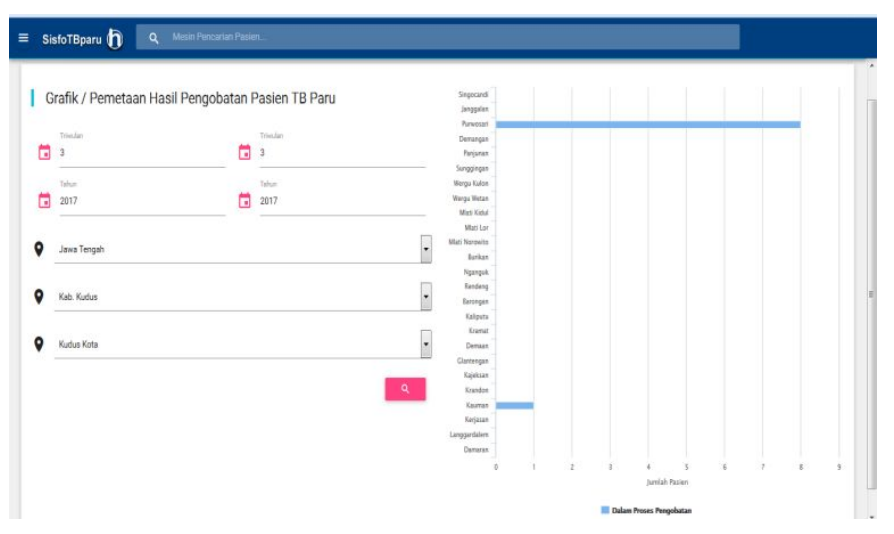

Gambar 8 Menu Grafik Sistem Informasi Pemantauan Pengobatan Pasien TB Paru

Pada menu Grafik, petugas dapat menginputkan periode triwulan dan tahun yang dikehendaki untuk melihat grafik jumlah perdesa pasien penderita TB Paru.

Setelah dilakukan ujicoba sistem, para pengguna diminta mengisi kuesioner ketergunaan sistem informasi dengan cara memberikan checklist pada tingkat persetujuan dengan score tertinggi tujuh. Aspek usability ini terdiri dari empat aspek, yaitu ketergunaan sistem (system usefulness), kualitas informasi (Infqual), kualitas antarmuka (interqual), dan kepuasan secara keseluruhan (overall). Dari 
hasil penghitungan rata -rata tertimbang, diperoleh hasil:

Ketergunaan sistem ( SysUse)

Ujicoba pada variabel Sysuse bertujuan untuk mengukur kelayakan tingkat penggunaan setelah Sistem informasi pemantauan pengobatan TB Paru di ujicobakan.

Tabel 1 Rekapitulasi hasil ujicoba Sysuse Sistem Informasi Pemantauan Pengobatan Pasien TB Paru

\begin{tabular}{lccccccccccr} 
& \multicolumn{1}{c}{ Responden } & \multicolumn{10}{c}{ PERTANYAAN } \\
\cline { 2 - 8 } & Q1 & Q2 & Q3 & Q4 & Q5 & Q6 & Q7 & Q8 & TOTAL \\
\hline R1 & 1 & 1 & 2 & 2 & 2 & 2 & 3 & 2 & 15 \\
R2 & 7 & 7 & 5 & 5 & 6 & 7 & 7 & 7 & 51 \\
R3 & 7 & 7 & 6 & 5 & 6 & 7 & 7 & 7 & 52 \\
R4 & 6 & 6 & 6 & 6 & 6 & 6 & 6 & 6 & 48 \\
R5 & 3 & 4 & 2 & 3 & 4 & 2 & 5 & 5 & 28 \\
R6 & 4 & 4 & 5 & 4 & 4 & 4 & 4 & 5 & 34 \\
R7 & 7 & 7 & 3 & 5 & 6 & 7 & 7 & 7 & 49 \\
R8 & 5 & 5 & 4 & 4 & 4 & 5 & 5 & 6 & 38 \\
R9 & 3 & 3 & 4 & 4 & 4 & 4 & 4 & 4 & 30 \\
R10 & 7 & 7 & 3 & 5 & 6 & 7 & 7 & 7 & 49 \\
R11 & 5 & 6 & 3 & 5 & 6 & 6 & 6 & 6 & 43 \\
R12 & 6 & 7 & 4 & 5 & 6 & 7 & 7 & 7 & 49
\end{tabular}

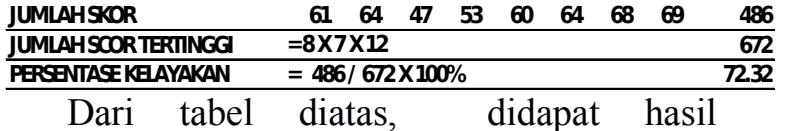
perhitungan kelayakan sebesar $72,32 \%$. Selanjutnya dibandingkan dengan kategori penilaian pada tabel 3.1. tentang penyesuaian interpretasi skala Likert. Hasil skor yang didapatkan berdasarkan tabel maka system usefullnes sistem informasi pemantauan pengobatan pasien TB Paru termasuk kategori Layak.

a. Kualitas informasi (InfoQual)

Pada variabel infoqual, bertujuan untuk menilai kelayakan informasi Sistem oleh pengguna setelah sistem ini diujicobakan.

Tabel 2 Rekapitulasi hasil ujicoba Infoqual Sistem Informasi Pemantauan Pengobatan Pasien TB Paru

\begin{tabular}{|c|c|c|c|c|c|c|c|c|c|}
\hline \multirow{2}{*}{\multicolumn{2}{|c|}{ Responden }} & \multicolumn{7}{|c|}{ PERTANYAAN } & \multirow{2}{*}{ TOTAL } \\
\hline & & Q9 & Q10 & Q11 & Q12 & Q13 & Q14 & Q15 & \\
\hline R1 & & 2 & 2 & 1 & 2 & 2 & 1 & 2 & 12 \\
\hline R2 & & 4 & 6 & 6 & 7 & 7 & 7 & 6 & 43 \\
\hline R3 & & 4 & 5 & 6 & 7 & 7 & 7 & 6 & 42 \\
\hline R4 & & 6 & 6 & 5 & 6 & 6 & 5 & 5 & 39 \\
\hline R5 & & 5 & 3 & 3 & 5 & 3 & 3 & 2 & 24 \\
\hline R6 & & 3 & 3 & 4 & 3 & 4 & 5 & 4 & 26 \\
\hline R7 & & 4 & 3 & 6 & 7 & 7 & 7 & 6 & 40 \\
\hline R8 & & 5 & 5 & 4 & 5 & 5 & 6 & 6 & 36 \\
\hline R9 & & 4 & 3 & 4 & 4 & 4 & 4 & 4 & 27 \\
\hline R10 & & 4 & 3 & 6 & 7 & 7 & 7 & 6 & 40 \\
\hline R11 & & 4 & 3 & 6 & 7 & 7 & 7 & 6 & 40 \\
\hline R12 & & 4 & 4 & 6 & 7 & 7 & 7 & 6 & 41 \\
\hline
\end{tabular}

\begin{tabular}{llllllllr} 
JUMLAHSKOR & 49 & 46 & 57 & 67 & 66 & 66 & 59 & 410 \\
\hline JUMLAHSCORTERTINGG & $=\mathbf{= 7 X 7 X 1 2}$ & & & & & 588 \\
\hline PERSENTASE KEAYAKAN & $\mathbf{= 4 1 0 X 5 8 8 / ~} \mathbf{1 0 0 \%}$ & & & $\mathbf{6 9 . 7 3}$
\end{tabular}

Dari hasil perhitungan tabel 2. di atas, selanjutnya dibandingkan dengan kategori penilaian tentang penyesuaian interpretasi skala Likert. Hasil skor yang didapatkan adalah $71,12 \%$ dan berdasarkan tabel maka information quality sistem informasi imunisasi termasuk kategori Layak.

b. Kualitas Antaramuka (InterQual)

Ujicoba pada variabel interqual bertujuan untuk mengukur kelayakan tingkat kualitas antarmuka sistem oleh pengguna.

Tabel 3 Rekapitulasi hasil ujicoba interqual Sistem Informasi Pemantauan Pengobatan Pasien TB Paru

\begin{tabular}{|c|c|c|c|c|c|}
\hline \multirow{2}{*}{ RESPONDEN } & \multicolumn{4}{|c|}{ PERTANYAAN } & \multirow{2}{*}{ TOTAL } \\
\hline & Q16 & Q 17 & Q 18 & & \\
\hline R1 & 3 & 3 & 2 & & 8 \\
\hline $\mathrm{R} 2$ & 6 & 5 & 6 & & 17 \\
\hline $\mathrm{R} 3$ & 5 & 5 & 6 & & 16 \\
\hline R4 & 6 & 5 & 6 & & 17 \\
\hline R5 & 6 & 6 & 6 & & 18 \\
\hline R6 & 4 & 4 & 4 & & 12 \\
\hline R7 & 5 & 5 & 6 & & 16 \\
\hline R8 & 5 & 5 & 6 & & 16 \\
\hline R9 & 3 & 3 & 4 & & 10 \\
\hline R10 & 5 & 5 & 6 & & 16 \\
\hline $\mathrm{R} 11$ & 5 & 5 & 5 & & 15 \\
\hline $\mathrm{R} 12$ & 5 & 5 & 5 & & 15 \\
\hline JUMLAHSKOR & & & 56 & 62 & 176 \\
\hline JUMLAHSCOR TERTINGG & $=3 \times 7$ & $<12$ & & & 252 \\
\hline PERSENTASEKGAYAKAN & $=176$ & $252 X$ & $100 \%$ & & 69.84 \\
\hline
\end{tabular}

Dari hasil perhitungan tabel 3 di atas, selanjutnya dibandingkan dengan kategori penilaian tentang penyesuaian interpretasi skala Likert. Hasil skor yang didapatkan adalah $69,84 \%$ dan berdasarkan tabel maka interface quality sistem informasi pemantauan pengobatan pasien TB Paru termasuk kategori Layak.

c. Kepuasan secara keseluruhan (OverAll) Hasil rekapitulasi untuk variabel system secara keseluruhan oleh pengguna.

Tabel 4 Rekapitulasi hasil ujicoba Overall Sistem Informasi Pemantauan Pengobatan Pasien TB Paru

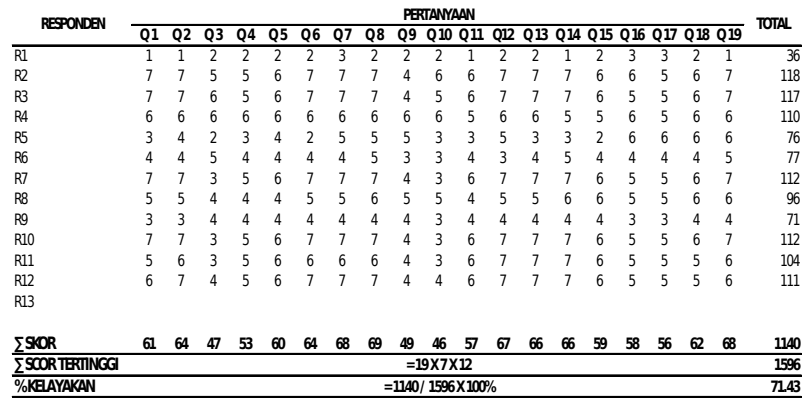


Dari hasil perhitungan tabel di atas, selanjutnya dibandingkan dengan kategori penilaian tentang penyesuaian interpretasi skala Likert. Hasil skor yang didapatkan adalah $71,43 \%$ dan berdasarkan tabel maka overall satisfaction sistem informasi Pemantauan Pengobatan Pasien TB Paru termasuk kategori Layak.

\section{KESIMPULAN}

Sistem informasi sebelum dikembangkan menggunakan pencatatan pengobatan manual, dimana jadwal minum obat pasien disimpan oleh petugas Puskesmas, sedangkan jadwal pemeriksaan dahak ulang dan pengambilan obat dibawa oleh pasien.

Sistem pemantauan pengobatan pasien TB paru yang dikembangkan berbasis website dengan pemrograman menggunakan $P H P$ dengan sistem operasi $M S$ Windows. Setelah sistem ini dikembangkan, petugas menjadi lebih mudah dalam memantau jadwal pengobatan pasien karena pasien sudah terbagi berdasarkan tanggal pengobatan, baik dalam jadwal minum obat, jadwal pengambilan obat maupun jadwal pemeriksaan dahak ulang. Selain itu dalam mengirim pesan petugas lebih mudah karena nomor hp pasien sudah tersimpan dalam basis data.

Evaluasi sistem informasi imunisasi menggunakan metode evaluasi berdasarkan usability dengan menggunakan PSSUQ yang dilihat dari respon responden terhadap 19 pertanyaan. Pengukuran ini meliputi 4 macam yaitu sistem usefullnes yang menghasilkan skor $72,32 \%$, information quality hasil skor yang didapatkan adalah $69,73 \%$, interface quality mendapatkan skor $69,84 \%$ yang berdasarkan tabel penyesuaian Likert termasuk kategori Layak. Kemudian pada pengukuran secara keseluruhan overall satisfaction menghasilkan skor $71,43 \%$ hal ini menunjukkan bahwa sistem informasi imunisasi termasuk kategori Layak.

\section{DAFTAR PUSTAKA}

1. WHO. Global Tuberculosis Report. Prancis: WHO; 2012.

2. RI BLKK. Riset Kesehatan Dasar 2013. Jakarta: Kemenkes RI; 2014.

3. Laporan Tahunan program TB Paru Kabupaten Kudus 2016.

4. Jumlah Pelanggan Telepon Indonesia menurut Jenis Penyelenggaraan Jaringan, 2010-2015. BPS; [cited 201717 Januari];
Available

from: www.bps.go.id/linkTabelStatis/view/id/18 44.

5. $\overline{\mathrm{RI}}$ KK. Pedoman Nasional Pengendalian Tuberculosis. Jakarta: Kementerian Kesehatan RI; 2014.

6. RI KK. Pedoman Nasional Pengendalian Tuberculosis. Jakarta: Kementerian Kesehatan RI; 2011.

7. JL W. Metode Desain \& Analisa Sistem. Edisi 6. Yogyakarta: Andi; 2004.

8. Mulyanto, A. Sistem Informasi Konsep dan aplikasi. Yogyakarta: Pustaka Pelajar; 2009.

9. Wilieyam, Sevani GN. Aplikasi Reminder Pengobatan Pasien Berbasis SMS Gateway. Jurnal Inkom. 2013;Volume 7 Nomor 1.

10. Hamzah, Winardi, S. Sistem Informasi Layanan SMS Gateway bagi Bidan dalamprogram PWS-KIA. Jurnal Teknologi Informasi 2014; Volume 8 Nomor 25 hal123-140 2014; .

11. Kadir, A. Pengenalan Sistem informasi. Yogyakarta: Andi; 2003.

12. Sommerville, I. Rekayasa Perangkat Lunak Edisi 6. Jakarta: Erlangga; 2003. 